\title{
PENYELESAIAN SENGKETA TERHADAP RISIKO YANG DIHADAPI PEMODAL PADA SECURITIES CROWDFUNDING DI INDONESIA
}

\author{
Nur Indah Putri Ramadhani, Rianda Dirkareshza \\ Fakultas Hukum Universitas Pembangunan Nasional Veteran Jakarta, Jakarta \\ nurindahputri@upnvj.ac.id
}

\begin{abstract}
Abstrak
Penelitian ini bertujuan untuk menganalisis kedudukan Peraturan Otoritas Jasa Keuangan Nomor 57 Tahun 2020 tentang Penawaran Efek Melalui Layanan Urun Dana Berbasis Teknologi Informasi pada sistem perundang-undangan di Indonesia dalam mengatur securities crowdfunding serta penyelesaian sengketa terhadap risiko yang dihadapi pemodal dalam securities crowdfunding di Indonesia. Securities crowdfunding sendiri merupakan penyempurnaan layanan urun dana equity crowdfunding yang sebelumnya sudah berjalan di Indonesia. Dalam penyempurnaannya ini, perubahan POJK 37/2018 tentang equity crowdfunding menjadi POJK 57/2020 tentang securities crowdfunding oleh Otoritas Jasa Keuangan (OJK) dikarenakan adanya kekurangan pada equity crowdfunding yang diantaranya adalah karena equity crowdfunding tidak dapat dimanfaatkan secara maksimal oleh usaha kecil menengah (UKM) serta pelaku usaha pemula (start-up company) karena keduanya bukan berbentuk perseroan terbatas, serta penerbitan efek yang hanya berupa saham. Metode penelitian yang digunakan adalah yuridis normatif dengan pendekatan statute approach dan conseptual approch. Pendekatan statute approach melalui POJK 57/2020 dan pendekatan conseptual approch menggunakan teori Hans Nawiansky mengenai theorie von stufenufbau der rechtsordnung. Hasil penelitian menyimpulkan bahwa pertama, berdasarkan teori theorie von stufenufbau der rechtsordnung dari Hans Nawiasky, kedudukan POJK dalam tata susunan norma hukum negara adalah sebagai Verordnung atau peraturan pelaksana dan POJK memiliki kekuatan hukum mengikat serta konsekuensi hukumnya adalah segala bentuk praktek security crowdfunding di Indonesia tunduk dan patuh pada ketentuan POJK 57/2020. Kedua, terhadap risiko yang dihadapi pemodal, penyelesaian sengketanya dapat dilakukan dengan 3 cara yaitu melalui internal dispute resolution, external dispute resolution dan pengadilan.
\end{abstract}

Kata Kunci: Pemodal; Penyelesaian Sengketa; Securities Crowdfunding

\section{DISPUTE RESOLUTION ON THE RISKS FACED BY INVESTORSIN INDONESIAN SECURITIES CROWDFUNDING}

\begin{abstract}
This study aims to analyze the Financial Services Authority Regulation (POJK) Number 57 of 2020's position concerning Securities Offering Through Information Technology-Based Crowdfunding Services in the Legislative System in Indonesia in regulating securities crowdfunding and resolving disputes regarding the risks faced by investors in securities crowdfunding in Indonesia. Securities crowdfunding itself is an improvement of equity crowdfunding which has been running in Indonesia. In the process of the improvement, the revision of Financial Services Authority Regulation number 37 of 2018 about equity crowdfunding to become the Financial Services Authority Regulation number 57 of 2020 about securities crowdfunding by Financial Services Authority (OJK) induced by an imperfection in the running of equity crowdfunding. Equity crowdfunding is unable to be maximally utilized by small and medium businesses (UKM) as well as start-up companies because both of them are not considered limited companies (PT). The securities issuance of small and medium businesses as well as start-up companies are also fixed in the form of shares sale. The research method used is normative juridical
\end{abstract}


p-ISSN : 2541-2345, e-ISSN : 2580-8842

with a statute approach and conceptual approach. The statute approach uses POJK 57/2020, and the conceptual approach uses Hans Nawiansky's theory of theorie von stufenufbau der rechtsordnung. The results of the study conclude that first, based on the theory of theorie von stufenufbau der rechtsordnung from Hans Nawiasky, the position of POJK in the arrangement of state legal norms is as Verordnung or implementing regulations, and POJK has binding legal force and the legal consequence is that all forms of security crowdfunding practices in Indonesia are subject to and comply with the provisions of POJK 57/2020. Second, regarding the risks faced by investors, dispute resolution can be solved in three ways, namely through internal dispute resolution, external dispute resolution, and courts.

Keywords: Financier;; Dispute Resolution; Securities Crowdfunding

\section{PENDAHULUAN}

\section{A. Latar Belakang}

Dengan pesatnya perkembangan teknologi, berkembang juga inovasi baru di sektor finansial sebagi bentuk perkembangan ekonomi digital yang dikenal dengan istilah financial technology (fintech). Salah satu bentuk dari fintech ini sendiri adalah crowdfunding. Konsep crowdfunding atau yang di Indonesia dikenal dengan urun dana adalah suatu kegiatan penggalangan dana di mana melibatkan orang banyak untuk memenuhi suatu kegiatan finansial bisnis dengan menggunakan internet. ${ }^{1}$ Konsep crowdfunding terdiri dari 4 macam yaitu donation based crowdfunding, reward based crowdfunding, lending based crowdfunding, serta equity based crowdfunding. Crowdfunding memainkan peran yang semakin penting untuk inovasi dan kewirausahaan, terutama sebagai pelengkap sumber benih lainnya. ${ }^{2}$ Munculnya equity crowdfunding sebagai inovasi fintech di Indonesia menjadi angin segar bagi pelaku bisnis untuk mendapatkan akses modal dengan lebih mudah. ${ }^{3}$ Penawaran equity crowdfunding, memang, menarik investor kecil dan profesional. ${ }^{4}$ Equity crowdfunding telah diakui keefektifannya dalam membiayai usaha baru dengan dibuktikan pada pendanaan 19 dari 24 bisnis dalam waktu 2 tahun pada platform penyelenggara Santara dan Bizhare. ${ }^{5}$

1 Ratna Hartanto, "Hubungan Hukum Para Pihak Dalam Layanan Urun Dana Melalui Penawaran Saham Berbasis Teknologi Informasi,” Jurnal Hukum Ius Quia Iustum 27, no. 1 (2020): 151-68.

2 Kourosh Shafi, “Investors' Evaluation Criteria in Equity Crowdfunding," Small Business Economics 56, no. 1 (2021): 3-37, https://doi.org/10.1007/s11187-019-00227-9.

${ }^{3}$ Evy Nur Sugiarti, Nur Diana, and M Cholid Mawardi, "Peran Fintech Dalam Meningkatkan Literasi Keuangan Pada Usaha Mikro Kecil Menengah Di Malang,” Jurnal Ilmiah Riset Akuntansi 8, no. 04 (2019).

${ }^{4}$ Douglas Cumming, Michele Meoli, and Silvio Vismara, "Does Equity Crowdfunding Democratize Entrepreneurial Finance?," Small Business Economics 56, no. 2 (2021): 533-52, https://doi.org/10.1007/s11187-019-00188-z.

5 Dalilatiyani Ajrinatia Aprihasyyati and Shoimatul Fitria, "Analisis Pengaruh Kinerja UMKM, Kepercayaan Dan Persepsi Risiko Terhadap Niat Investasi Pada UMKM Melalui Platform Equity Crowdfunding Di Indonesia,” Diponegoro Journal of Management 9, no. 2 (2021). 
Santara dan Bizhare merupakan dua dari tiga perusahaan penyelenggara yang pada 31 Desember 2019 telah mendapat izin Otoritas Jasa Keuangan (OJK) dalam menjalankan equity crowdfunding di Indonesia, serta satu perusahaan lainnya adalah CrowdDana. ${ }^{6}$ Equity crowdfunding sendiri diatur oleh OJK dalam Peraturan Otoritas Jasa Keuangan No. 37/POJK.04/2018 (selanjutnya disebut POJK 37/2018) di mana dalam penyelenggaraannya masih banyak kekurangan sehingga pada tahun 2020, OJK menyempurnakan equity crowdfunding menjadi securities crowdfunding berdasarkan Peraturan Otoritas Jasa Keuangan Nomor 57 Tahun 2020 tentang Penawaran Efek Melalui Layanan Urun Dana Berbasis Teknologi Informasi (untuk selanjutnya disebut POJK 57/2020).

Dalam penyempurnaannya, perubahan POJK 37/2018 tentang equity crowdfunding menjadi POJK 57/2020 tentang securities crowdfunding oleh OJK dikarenakan adanya kekurangan pada equity crowdfunding yang diantaranya adalah karena equity crowdfunding tidak dapat dimanfaatkan secara maksimal oleh usaha kecil menengah (UKM) serta pelaku usaha pemula (start-up company) karena keduanya bukan berbentuk perseroan terbatas serta penerbitan efek yang hanya berupa saham. Sehubungan dengan hal tersebut, penyempuraan menjadi securities crowdfunding berimplikasi pada pemanfaatan secara maksimal pembiayaan urun dana pada UKM dan start-up company serta memperluas penerbitan efek yang kini mencangkup utang atau obligasi, dan sukuk. ${ }^{7}$ Adanya 16 calon penyelenggara securities crowdfunding pada akhir Desember 2020 yang mengajukan izin untuk menjadi penyelenggara yang sah dan terdaftar pada OJK hanya dalam selang waktu dua bulan setelah diterbitkannya POJK 57/2020 mengenai securities crowdfunding di Indonesia membuktikan bahwa adanya respon pasar yang positif dari perkembangan ini. Di samping terus berkembangnya fintech equity crowdfunding menjadi securities crowdfunding, belum adanya undang-undang yang jelas dalam mengatur perlindungan hukum bagi penggunanya menimbulkan kekhawatiran. Padahal, para pengguna perlu dilindungi haknya baik dari modal yang diberikan dan juga perlindungan terhadap data privasinya yang didaftarkan pada platform penyelengara.

${ }^{6}$ Teuku Ghalib Muadzan and Bernardus Yuliarto Nugroho, "Analisis Optimasi Model Bisnis Perusahaan Fintech Berbasis Equity Crowdfunding Menggunakan Business Model Canvas," Syntax Literate; Jurnal Ilmiah Indonesia 6, no. 6 (2021).

${ }^{7}$ Gigih Prahastoro, Firdaus Yuni Dharta, and Rastri Kusumaningrum, "Strategi Komunikasi Pemasaran Layanan Securities Crowdfunding Dalam Menarik Minat Masyarakat Untuk Berinvestasi Di Sektor UKM," Kinerja 18, no. 2 (2021): 210-17. 
Kedudukan pemodal dapat dikatakan lebih rendah dari penyelenggara dilihat dari perjanjian antara pemodal dan penyelenggara di mana tertuang dalam perjanjian baku serta dana pemodal disetorkan secara penuh pada masa penawaran saham. Hal ini menimbulkan risiko-risiko yang akan dihadapi pemodal. Berdasarkan kemungkinan risiko yang ada tersebut menjadi suatu hal yang menarik untuk dibahas berkaitan dengan kedudukan POJK sebagai dasar hukum penyelenggaraan securities crowdfunding dan OJK sebagai lembaga yang memiliki fungsi dalam hal pengaturan serta pengawasan terhadap seluruh kegiatan pada sektor jasa keuangan ${ }^{8}$ salah satunya dalam penyelenggaraan securities crowdfunding. Tidak hanya itu, kemungkinan risiko yang muncul dari penyelenggaraan securities crowdfunding perlu dilakukan penelitian untuk menemukan cara penyelesaian sengketa yang timbul dari pelaksanaan securities crowdfunding di Indonesia.

Penelitian tentang securities crowdfunding dikaji oleh Prahastoro dkk (2021). Penelitian tersebut membahas tentang strategi dalam komunikasi pemasaran pada salah satu perusahaan rintisan teknologi berbasis securities crowdfunding. Hasil dari penelitian ini adalah strategi komunikasi yang dilakukan oleh salah satu perusahaan rintisan teknologi berbasis securities crowdfunding adalah dengan memanfaatkan sosial media, berkolaborasi dengan media lokal dan nasional, membuat konten dan artikel pada blog perusahaan, serta berpartisipasi pada acara-acara yang berhubungan dengan start-up dan investasi. ${ }^{9}$

Penelitian serupa juga dilakukan oleh Kadir (2021) di mana penelitian ini membahas keterlibatan dan kedudukan DSN-MUI pada penyelenggaraan securities crowdfunding. Hasil dari penelitian ini adalah penawaran sukuk melalui platform securities crowdfunding, yang menjadikan sukuk berbeda dengan efek lainnya, keharusan memiliki Dewan Pengawas Syariah (DPS) untuk melakukan screening pada produk yang dikeluarkan melalui sukuk. Upaya ini untuk menjamin kegiatan sukuk dalam securities crowdfunding dapat berjalan sesuai prinsip syariah. ${ }^{10}$

Penelitian tentang securities crowdfunding juga dilakukan oleh Saputra (2021) di mana dalam penelitian ini mengkaji mengenai bagaimana relevansi securities crowdfunding dalam nilai-nilai ekonomi Pancasila melalui pembiayaan UMKM yang ada. Hasil dari penelitian ini menunjukan bahwa

\footnotetext{
${ }^{8}$ S E Kasmir, "Bank Dan Lembaga Keuangan Lainnya Edisi Revisi,” 2018.

9 Prahastoro, Dharta, and Kusumaningrum, "Strategi Komunikasi Pemasaran Layanan Securities Crowdfunding Dalam Menarik Minat Masyarakat Untuk Berinvestasi Di Sektor UKM."

${ }^{10}$ Muhammad Rusydi Kadir, "Shariah Compliance Pada Investasi Sukuk Dalam Securities Crowdfunding Di Indonesia,” Jurnal Ilmu Perbankan Dan Keuangan Syariah 3, no. 1 (2021): 16-29.
} 
securities crowdfunding selaras dengan Pancasila khususnya implementasi ekonomi kerakyatan dalam masyarakat. Peran masyarakat yang melakukan gotong-royong yang menjadi dasar dari perekonomian kerakyatan dapat diimplementasikan dalam UKM. Pemerintah seharusnya menyiapkan struktur hukum yang melindungi pemodal. ${ }^{11}$

Penelitian ini melengkapi penelitian sebelumnya yang membahas mengenai securities crowdfunding di Indonesia. Penelitian yang dilakukan oleh Prahastoro lebih membahas mengenai strategi yang dilakukan oleh perusahaan penyelenggara dalam securities crowdfunding untuk melakukan pemasaran. Sedangkan penelitian oleh Kadir, lebih membahas mengenai keterlibatan dan kedudukan DSN-MUI pada penyelenggaraan securities crowdfunding. Dan penelitian yang dilakukan oleh Saputra dan Qurrata lebih membahas pada relevansi securities crowdfunding dalam nilai-nilai ekonomi Pancasila melalui pembiayaan UMKM. Berdasarkan ketiga penelitian sebelumnya yang sudah disebutkan, maka terdapat persamaan dan perbedaan. Persamaannya ada pada sama-sama meneliti mengenai securities crowdfunding. Sedangkan perbedaannya ada pada rumusan masalah. Penelitian ini diorientasikan pada permasalahan yang lebih kompleks, yaitu mengenai kedudukan POJK yang dihubungkan dengan teori Hans Nawiansky serta bentuk-bentuk risiko yang kemungkinan dihadapi oleh pemodal dalam securities crowdfunding. Tujuan dari penelitian ini adalah untuk menganalisis kedudukan POJK 57/2020 pada sistem perundang-undangan di Indonesia dalam mengatur securities crowdfunding serta penyelesaian sengketa terhadap risiko yang dihadapi pemodal dalam securities crowdfunding di Indonesia.

\section{B. Permasalahan}

Dari uraian di atas, rumusan masalah penelitian ini berfokus pada dua hal, yaitu: pertama, bagaimana kedudukan POJK 57/2020 pada sistem perundang-undanganan di Indonesia dalam mengatur securities crowdfunding? Kedua, bagaimana penyelesaian sengketa terhadap risiko yang dihadapi pemodal dalam securities crowdfunding di Indonesia?

\section{Metode Penelitian}

Dalam penelitian ini dipergunakan penelitian hukum normatif, di mana penelitian hukum normatif dilakukan untuk menemukan suatu kebenaran dengan berdasarkan logika keilmuan dari sisi normatif. Peter Muhammad berpendapat bahwa tujuan dilakukannya penelitian hukum normatif adalah untuk menghasilkan suatu argumentasi maupun konsep baru sebagai preskripsi

\footnotetext{
${ }^{11}$ Mochamad Dandy Hadi Saputra and Vika Annisa Qurrata, "Securities Crowdfunding: Bagaimana Relevansinya Pada Nilai-Nilai Pancasila?," in Prosiding Seminar Nasional Ekonomi Pembangunan, vol. 1, 2021, 28-37.
} 
terhadap penyelesaian masalah yang dihadapi. ${ }^{12}$ Kemudian digunakan pendekatan melalui statute approach dan conseptual approch. Pendekatan statute approach sebagai pendekatan perundang-undangan dilakukan dengan merujuk pada regulasi atas isu hukum yang dibahas ${ }^{13}$ yaitu melalui POJK 57/2020 serta pendekatan conseptual approch sebagai pendekatan konseptual dilakukan melalui pendekatan atas pandangan serta doktrin yang berkembang dalam ilmu hukum yang dalam penulisan ini menggunakan teori Hans Nawiansky mengenai theorie von stufenufbau der rechtsordnung. ${ }^{14}$

\section{HASIL DAN PEMBAHASAN}

\section{A. Kedudukan POJK 57/2020 Pada Sistem Perundang-Undanganan Di Indonesia Dalam Mengatur Securities Crowdfunding}

Kegiatan securities crowdfunding di Indonesia hanya diatur oleh Otoritas Jasa Keuangan (OJK) melalui POJK 57/2020 tentang Penawaran Efek Melalui Layanan Urun Dana Berbasis Teknologi Informasi. Kegiatan securities crowdfunding sendiri merupakan penggalangan dana secara terbuka dengan menggunakan internet untuk mencari penyediaan sumber keuangan ${ }^{15}$ yang memiliki perjanjian bersifat finansial seperti profit-sharing, revenue-sharing, atau ketentuan manfaat uang lainnya. Dalam penerapannya di Indonesia, securities crowdfunding digunakan sebagai penghimpunan dana oleh pelaku UKM dan start-up company dengan skema patungan melalui platform fintech menggunakan internet sehingga UKM dan start-up company dapat dengan mudah mendapatkan pembiayaan dari investor. Selain dapat membeli saham atau kepemilikan dari UKM dan start-up company, dalam securities crowdfunding, investor juga dapat membeli dalam bentuk obligasi dan sukuk. ${ }^{16}$ OJK yang dalam hal ini melakukan pengaturan pada kegiatan securities crowdfunding di Indonesia merupakan lembaga independen yang kedudukannya berada di luar pemerintahan ${ }^{17}$ serta memiliki fungsi menyelenggarakan sistem pengaturan dan pengawasan terintegrasi yang salah satunya pada ruang lingkup kegiatan jasa keuangan di sektor pasar

\footnotetext{
12 Peter Mahmud Marzuki, "Penelitian Hukum, Edisi Pertama, Cet," VII, Kencana Prenada (Jakarta, Media Group, 2011), 2011.

13 Peter Mahmud Marzuki, "Penelitian Hukum (Edisi Kesatu)” (Jakarta, Kencana, 2010).

${ }^{14}$ Marzuki.

15 Paul Belleflamme, Thomas Lambert, and Armin Schwienbacher, "Crowdfunding: Tapping the Right Crowd," Journal of Business Venturing 29, no. 5 (2014): 585-609.

16 Prahastoro, Dharta, and Kusumaningrum, "Strategi Komunikasi Pemasaran Layanan Securities Crowdfunding Dalam Menarik Minat Masyarakat Untuk Berinvestasi Di Sektor UKM."

17 Wiwin Sri Rahyani, "Independensi Otoritas Jasa Keuangan Dalam Perspektif Undang-Undang Nomor 21 Tahun 2011 Tentang Otoritas Jasa Keuangan (The Independence Of The Financial Services Authority Perspectives In Law Number 21 Year 2011 Concerning The," Daftar Isi, n.d., 361 .
} 
modal. ${ }^{18}$ Pengaturan securities crowdfunding yang tertuang dalam POJK 57/2020 ini terdiri dari 13 bab.

Pengaturan securities crowdfunding di Indonesia yang hanya melalui POJK 57/2020 tanpa adanya undang-undang yang lebih tinggi dalam mengatur penyelenggaraannya membuat sebuah tanda tanya besar, kegiatan securities crowdfunding di Indonesia ini dapat tetap berlangsung serta memiliki kekuatan hukum tetap. Sebab, apabila dilihat dalam tata urutan jenis dan hierarki peraturan perundang-undangan yang terdapat pada Undang-Undang Nomor 12 tahun 2011 tentang Pembentukan Peraturan Perundang-undangan (selanjutnya disebut UU 12/2012), POJK sebagaimana yang dalam pembahasan ini mengatur mengenai securities crowdfunding di Indonesia tidak termasuk di dalamnya. Dalam pasal 7 ayat (1) UU 12/2012, yang masuk ke dalam jenis dan hierarki peraturan perundang-undangan di Indonesia adalah:

a. Undang-Undang Dasar Negara Republik Indonesia Tahun 1945;

b. Ketetapan Majelis Permusyawaratan Rakyat;

c. Undang-undang/Peraturan Pemerintah Pengganti Undang-undang;

d. Peraturan Pemerintah;

e. Peraturan Presiden;

f. Peraturan Daerah Provinsi; dan

g. Peraturan Daerah Kabupaten/Kota.

Pembahasan mengenai hierarki peraturan perundang-undangan di Indonesia, pendasaran terhadap teori Hans Nawiansky tentang theorie von stufenufbau der rechtsordnung harus dibicarakan. Hal ini karena penerapannya dalam struktur tata hukum di Indonesia oleh A. Hamid S. Attamimi yang terimplementasikan pada UU 10/2004 maupun UU 12/2011. ${ }^{19}$ Teori Hans Nawiasky ini menjelaskan bahwa selain norma itu berlapis-lapis dan berjenjang-jenjang, norma hukum juga berkelompok-kelompok. Pengelompokkan norma hukum dalam suatu negara tersusun dalam tata susunan norma hukum negara (die Stufenordnung der Rechtsnormen). ${ }^{20}$ Susunan norma menurut teori ini serta implementasinya

\footnotetext{
18 Hasbi Hasan, "Efektivitas Pengawasan Otoritas Jasa Keuangan Terhadap Lembaga Perbankan Syariah,” Jurnal Legislasi Indonesia 9, no. 3 (2012): 373-94.

19 Bivitri Susanti, "Menyoal Jenis Dan Hierarki Peraturan Perundang-Undangan Di Indonesia," Jentera: Jurnal Hukum 1, no. 2 (2017): 128-43.

20 Bambang Antariksa, "Penerapan Hierarki Peraturan Perundang-Undangan Dalam Ketatanegaran Indonesia,” Deliberatif 1, no. 1 (2017): 24-41.
} 
pada struktur tata hukum di Indonesia oleh A. Hamid S. Attamimi adalah sebagai berikut: ${ }^{21}$

1) Saats Fundamentalnorm/ Grundnorm

Staats fundamentalnorm/ grundnorm atau norma fundamental negara merupakan kelompok pertama dan paling teratas posisinya pada hierarki norma hukum suatu negara. Norma ini memiliki kedudukan yang paling tinggi, sebab norma ini merupakan dasar yang digunakan untuk membentuk konstitusi atau undang-undang dasar. Hakikat hukum staats fundamentalnorm adalah syarat untuk berlakunya konstitusi ${ }^{22}$ di mana menjadi landasan dasar filosofis bagi negara. ${ }^{23}$ Staats fundamentalnorm/ grundnorm berupa Pancasila (Pembukaan UUD RI Tahun 1945).

2) Staatsgrund Gezets

Staatsgrund gezets atau aturan dasar negara adalah kelompok kedua pada hierarki norma hukum suatu negara di mana norma ini merupakan aturan-aturan umum yang general. Isi norma ini adalah aturan terhadap pembagian kekuasaan serta hubungan antar negara dan warga negara. ${ }^{24}$ Staatsgrund gezets berupa Batang Tubuh UUD 1945, Tap MPR, dan Konvensi Ketatanegaraan.

3) Formell Gezets

Formell gezets atau undang-undang adalah kelompok ketiga dalam hierarki norma hukum negara di mana norma ini lebih terinci dan konkret, serta sudah langsung dapat berlaku di masyarakat. ${ }^{25}$ Formell gezets berupa undang-undang.

4) Verordnung \& Autonome Satzung

Verordnung atau peraturan pelaksana dan autonome atau aturan otonomi adalah kelompok keempat dalam hierarki norma hukum negara di mana norma ini berada dibawah undang-undang dengan memiliki fungsi untuk menyelenggarakan undang-undang tersebut. ${ }^{26}$ Dalam penerapannya, peraturan pelaksana bersumber dari kewenangan delegasi, sedangkan

21 Jimly Asshiddiqie and Muchamad Ali Safa'at, Teori Hans Kelsen Tentang Hukum (Mahkamah Konstitusi RI, Sekretariat Jenderal dan Kenpaniteraan, 2006).

22 Arifin.

23 Ni'matul Huda, "Kedudukan Peraturan Daerah Dalam Hierarki Peraturan Perundang-Undangan,” Jurnal Hukum Ius Quia IusTum 13, no. 1 (2006): 27-37.

${ }^{24}$ Arifin, "Eksistensi Peraturan Daerah Dalam Sistem Hukum Nasional Dan Implementasinya Terhadap Otonomi Daerah."

25 Arifin.

26 Arifin. 
aturan otonom bersumber dari atribusi. ${ }^{27}$ Adapun delegasi merupakan pelimpahan kewenangan dalam membentuk peraturan perundang-undangan dari peraturan perundang-undangan yang lebih tinggi ke peraturan perundang-undangan yang lebih rendah ${ }^{28}$ dan bersifat "diwakilkan" serta bersifat temporer sepanjang masih adanya pelimpahan tersebut. Sedangkan atribusi merupakan pemberian kewenangan dalam membentuk peraturan perundang-undangan yang diberikan kepada suatu lembaga negara atau pemerintahaan oleh undang-undang dasar atau undang-undang. ${ }^{29}$ Verordnung \& autonome satzung secara hierarkis mulai dari peraturan pemerintah hingga keputusan bupati atau walikota.

Akibat dari adanya kelompok hierarki di atas, maka berlakunya norma hukum yang lebih rendah akan sangat tergantung pada norma yang lebih tinggi di atasnya. Ketentuan yang lebih tinggi menjadi das sollen untuk pembentukan norma yang lebih rendah, norma hukum yang posisinya di bawah maka isinya tidak boleh bertentangan dengan norma hukum di atasnya dan apabila dicabutnya norma hukum yang lebih tinggi yang menjadi dasar sumber berlaku norma yang lebih rendah, maka norma yang lebih rendah tersebut tidak berlaku lagi. ${ }^{30}$

Berdasarkan penjabaran terhadap teori Hans Nawiasky di atas yang diterapkan pada struktur hierarki tata hukum di Indonesia, Pancasila berfungsi sebagai norma hukum tertinggi atau norma fundamental negara. Pancasila yang merupakan dasar negara menjadi sumber dan dasar atas pembentukan norma-norma hukum pada Batang Tubuh UUD 1945, demikian pula seterusnya ke bawah. Keberadaan POJK dalam struktur hierarki tata hukum di Indonesia masuk dalam Verordnung, yaitu aturan pelaksana yang kedudukannya ada di bawah undang-undang memiliki fungsi untuk melaksanakan dan menyelenggarakan ketentuan dalam undang-undang, di mana pelaksanaan ini atas kewenangan delegasi. Sehingga di sini terlihat adanya aturan pelaksana melalui delegasi dari peraturan

${ }^{27}$ Permadi Setyonagoro, "Wacana Hukum Uji Konstitusionalitas Produk Hukum Peraturan Daerah (Legal Discourse About Testing Constitutionality Of Regional Regulations)," Cakrawala 13, no. 1 (2019).

28 Maria Farida Indrati Soeprapto, Ilmu Perundang-Undangan 2: Proses Dan Teknik Penyusunan (PT Kanisius, 2018).

${ }^{29}$ Maria Farida Indrati, "Ilmu Perundang-Undangan: Dasar-Dasar Dan Pembentukannya," Jakarta. Kanisius, 1998.

${ }^{30}$ Taufiqurrohman Syahuri, Hukum Konstitusi: Proses Dan Prosedur Perubahan UUD Di Indonesia 1945-2002 Serta Perbandingannya Dengan Konstitusi Negara Lain Di Dunia (Ghalia Indonesia, 2004). 
perundang-undangan yang lebih tinggi ke peraturan perundang-undangan yang lebih rendah.

Tidak terdapatnya POJK dalam pasal 7 ayat (1) UU 12/2011 dikarenakan peraturan perundang-undangan yang berlaku di Indonesia dibedakan menjadi dua, yaitu: ${ }^{31}$

1) Peraturan yang masuk sebagai jenis dan hierarki peraturan perundang-undangan

Di mana peraturan ini terdiri atas: Undang-Undang Dasar, Undang-Undang, Peraturan Pemerintah Pengganti Undang-Undang, Peraturan Pemerintah, Peraturan Presiden, dan Peraturan Daerah, hal ini berdasarkan Pasal 7 ayat (1) UU 12/2011.

2) Jenis peraturan lainnya

Di mana peraturan ini tidak termasuk sebagai jenis dan hierarki peraturan perundang-undangan tetapi keberadaannya tetap diakui serta memiliki kekuatan hukum mengikat selama diatur oleh peraturan perundang-undangan yang lebih tinggi, di mana hal ini berdasarkan pasal 8 ayat (1) dan (2) UU 12/2011.

Ketika dikaitkan dengan pasal 8 ayat (1) dan (2) UU 12/2011, maka POJK masuk sebagai peraturan di dalamnya, sebab pada pasal 8 ayat (1) dan (2) UU 12/2011 ini dijelaskan bahwa selain jenis peraturan perundang-undangan yang dimaksud dalam pasal 8 ayat (1) UU 12/2011 adalah peraturan yang ditetapkan oleh Majelis Permusyawaratan Rakyat, Dewan Perwakilan Rakyat, Dewan Perwakilan Daerah, Mahkamah Agung, Mahkamah Konstitusi, Badan Pemeriksa Keuangan, Komisi Yudisial, Bank Indonesia, Menteri, badan, lembaga, atau komisi yang setingkat yang dibentuk dengan Undang-Undang atau Pemerintah atas perintah Undang-Undang, Dewan Perwakilan Rakyat Daerah Provinsi, Gubernur, Dewan Perwakilan Rakyat Daerah Kabupaten/Kota, Bupati/Walikota, Kepala Desa atau yang setingkat diakui keberadaannya dan mempunyai kekuatan hukum mengikat sepanjang diperintahkan oleh peraturan perundang-undangan yang lebih tinggi atau dibentuk berdasarkan kewenangan.

POJK sendiri adalah produk hukum yang dikeluarkan oleh OJK untuk melaksanakan dan menyelenggarakan apa yang ada dalam Undang-undang Nomor 21 Tahun 2011 tentang Otoritas Jasa Keuangan. Sehingga, regulasi atas security crowdfunding di Indonesia melalui POJK 57/2020 yang di mana dalam pelaksanaanya mendapatkan pelimpahan kewenangan dari

\footnotetext{
${ }^{31}$ Susanti, "Menyoal Jenis Dan Hierarki Peraturan Perundang-Undangan Di Indonesia."
} 
Undang-undang Pasar Modal dan Undang-undang Otoritas Jasa Keuangan, maka ketentuan POJK 57/2020 ini memiliki kekuatan hukum mengikat sehingga konsekuensi hukumnya adalah segala bentuk praktek security crowdfunding di Indonesia tunduk dan patuh pada ketentuan POJK 57/2020 yang diatur dan diawasi oleh Otoritas Jasa Keungan.

\section{B. Penyelesaian Sengketa Terhadap Risiko Yang Ditimbulkan Penyelenggara Dalam Securities Crowdfunding Di Indonesia}

Di samping kemudahan mendapatkan modal yang ditawarkan oleh securities crowdfunding, terdapat pula risiko yang mungkin dihadapi baik bagi pemodal ataupun penerbit. Penyelenggara dalam menyelenggarakan securities crowdfunding memiliki peran yang sangat penting, sebab setelah mendapat izin dari OJK, penyelenggara wajib memastikan keamanan serta kelancaran proses securities crowdfunding di Indonesia. Dalam POJK $57 / 2020$, ketentuan mengenai risiko diatur dalam pasal 16 di mana penyelenggara wajib memasukkan risiko dalam platformnya, minimal risiko usaha, risiko investasi, likuiditas, kegagalan atas sistem elektronik, kelangkaan pembagian keuntungan atau dilusi kepemilikan saham dan gagal bayar atas Efek bersifat utang atau Sukuk.

Kedudukan pemodal dapat dikatakan lebih rendah dari penyelenggara dilihat dari perjanjian antara pemodal dan penyelenggara di mana tertuang dalam perjanjian baku serta dana pemodal disetorkan secara penuh pada masa penawaran saham. Hal ini menimbulkan risiko-risiko yang akan dihadapi pemodal. Adanya risiko ini menyebabkan munculnya sengketa di mana dalam POJK 57/2020 tidak dijelaskan secara rinci bagaimana bentuk risiko-risiko yang akan dihadapi beserta penyelesaian sengketanya, melainkan hanya menjelaskan dapat dilakukan dengan 3 cara yaitu melalui internal dispute resolution, external dispute resolution dan pengadilan. Penyelesaian sengketa sendiri termasuk sebagai perlindungan hukum represif yaitu perlindungan hukum yang tujuannya adalah untuk menyelesaikan permasalahan hukum. ${ }^{32}$ Penyelesaian sengketa bisnis pinjam meminjam berbasis teknologi finansial dapat dilakukan melalui jalur litigasi (pengadilan) maupun non-litigasi (di luar pengadilan). ${ }^{33}$ Berkaitan dengan 3 cara penyelesaian sengketa dalam equity crowdfunding yang diatur dalam POJK 57/2020, maka berikut adalah risiko-risiko dalam equity crowdfunding yang dipetakan berdasarkan tempat menyelesaikan sengketanya:

${ }^{32}$ M Hadjon Philipus, "Perlindungan Hukum Bagi Rakyat Indonesia," Bina Ilmu, Surabaya

33 Iswi Hariyani, "Perlindungan Hukum Dan Penyelesaian Sengketa Bisnis Jasa PM-Tekfin," Jurnal Legislasi Indonesia 14, no. 3 (2018): 345-58. 
a. Non litigasi

1) Internal Dispute Resolution

Internal dispute resolution merupakan suatu bentuk penyelesaian pengaduan oleh lembaga jasa keuangan itu sendiri. Dalam pasal 32 POJK Nomor 1/POJK.07/2013 tentang Perlindungan Konsumen Sektor Jasa Keuangan, pelaku usaha jasa keuangan mempunyai kewajiban untuk memiliki serta menjalankan mekanisme pelayanan dan penyelesaian pengaduan bagi konsumen. Hal ini juga dipertegas dalam pasal 16 ayat (1) huruf m POJK 57/2020 bahwa penyelenggara wajib untuk menyediakan layanan penanganan pengaduan. Segala bentuk risiko dari penggunaan platform securities crowdfunding perlu dibuatkan penggaduan pada platform penyelenggara securities crowdfunding untuk dilakukan tindak lanjut. Konsumen wajib melakukan pengaduan dan penyelesaian sengketa secara internal dengan pihak platform penyelenggara terlebih dahulu dan pihak platform penyelenggara wajib memberikan penyelesaian atas aduan yang masuk. Penyelenggara securities crowdfunding wajib segera melakukan tindak lanjut serta memberikan penyelesaian pengaduan paling lama 20 hari kerja setelah tanggal diterimanya pengaduan dan dapat diperpanjang ketika terdapat kondisi tertentu. Apabila sengketa masih terselesaikan secara internal, maka atas kesepakatan para pihak yang bersengketa, sengketa tersebut dapat diselesaikan melalui external dispute resolution.

2) External Dispute Resolution

External dispute resolution adalah suatu bentuk penyelesaian sengketa yang dilakukan oleh lembaga berwenang baik melalui pengadilan dan/atau di luar lembaga peradilan. Penyelesaian sengketa oleh lembaga di luar peradilan dialakukan oleh lembaga alternatif penyelesaian sengketa yang sudah ditentukan OJK serta dimuat dalam Daftar Lembaga Alternatif Penyelesaian Sengketa (LAPS). ${ }^{34}$ Secara umum, LAPS memiliki 3 (tiga) layanan penyelesaian sengketa, yaitu dapat melalui mediasi, ajudikasi dan arbitrase. Untuk jalur ajudikasi dan arbitrase tidak dapat ditempuh

34 Tika Purnami, "Perlindungan Hukum Bagi Debitur Dalam Pinjaman Online Berbasis Peer To Peer Lending," Jurnal Kertha Wicara 9, no. 12 (2020): 1-10. 
apabila sebelumnya tidak melalui jalur mediasi. ${ }^{35}$ Di Indonesia, OJK mengatur 6 LAPS dalam memberikan penyelesaian sengketa di sektor jasa keuangan berdasarkan Peraturan OJK nomor 1/ POJK.07/ 2014, yaitu: ${ }^{36}$

1. Lembaga Alternatif Penyelesaian Sengketa Perbankan Indonesia (LAPSPI),

2. Badan Arbitrase Pasar Modal Indonesia (BAPMI),

3. Badan Mediasi dan Arbitrase Asuransi Indonesia (BMAI),

4. Badan Arbitrase dan Mediasi Perusahaan Penjaminan Indonesia (BAMPPI),

5. Badan Mediasi Pembiayaan dan Pegadaian Indonesia (BMPPI), dan

6. Badan Mediasi Dana Pensiun (BMDP).

Dalam penyelesaian sengketa mengenai securities crowdfunding, maka diselesaikan pada Badan Arbitrase Pasar Modal Indonesia (BAPMI). Untuk melakukan penyelesaian sengketa di BAPMI, dibutuhkan kesepakatan antar para pihak yang bersengketa bahwa penyelesaian sengketa dilakukan melalui BAPMI. Kkesepakatan tersebut dituangkan dalam perjanjian bisnis di antara mereka. Kemudian juga perlu adanya permohonan tertulis kepada BAPMI dari para pihak. BAPMI memiliki 4 (empat) bentuk penyelesaian sengketa yang dapat dipilih oleh para pihak, yaitu pendapat mengikat, mediasi, adjudikasi, dan arbitrase. ${ }^{37}$ Setelah adanya putusan yang dikeluarkan oleh BAPMI maka putusan yang sudah ditetapkan apabila diterima oleh masing-masing pihak maka putusan tersebut harus didaftrakan kepada Pengadilan Negeri dearah hukum yang berwenang. Setelah dilakukan pendaftaran dan putusan dijalankan maka selesai proses penyelesaian sengketa tersebut. Berkaitan dengan risiko pemodal pada securities crowdfunding, maka risiko yang mungkin diselesaikan melalui BAPMI adalah:

1. Risiko keterlambatan pengembalian dana

Dalam pasal 34 ayat POJK 57/2020 telah diatur mengenai pengembalian dana pemodal apabila jumlah minimum dana dalam penawaran efek tidak terpenuhi, maka penawaran efek tersebut batal demi hukum dan penyelenggara wajib

35 Deza Pasma Juniar, Agus Suwandono, and Helitha Novianty Muchtar, "Perlindungan Hukum Terhadap Konsumen Peer To Peer Lending Atas Perbuatan Melawan Hukum Yang Dilakukan Oleh Debt Collector," Widya Yuridika: Jurnal Hukum 3, no. 2 (2020): 107-18.

${ }^{36}$ Hariyani, "Perlindungan Hukum Dan Penyelesaian Sengketa Bisnis Jasa PM-Tekfin."

${ }^{37}$ Frans Hendra Winarta, "Hukum Penyelesaian Sengketa," 2013. 
mengembalikan dana pemodal yang telah disetorkan pada escrow account paling lambat 2 (dua) hari kerja. Bila mana penyelenggara tidak mengembalikan dana pemodal melebihi 2 (dua) hari kerja baik disengaja maupun tidak disengaja, maka pemodal dapat membawa permasalahan ini pada BAPMI.

2. Risiko berubahnya syarat, biaya, manfaat, risiko dan ketentuan yang tercantum pada dokumen/perjanjian

Pelaku usaha jasa keuangan yang dalam hal ini adalah penyelenggara securities crowdfunding wajib memberikan informasi kepada pemodal dan penerbit atas setiap adanya perubahan baik dari syarat, biaya, manfaat, risiko dan ketentuan yang tercantum pada dokumen/perjanjian paling lama 30 (tiga puluh) hari sebelum diberlakukannya perubahan tersebut. Apabila ternyata pemodal dan penerbit tidak diberitahu samapai dengan perubahan tersebut berlaku dan dari perubahan tersebut menimbulkan kerugian, maka keduanya dapat mengajukan penyelesaian sengketa ke BAPMI.

3. Risiko tidak dicatatnya kepemilikan saham pemodal pada daftar pemegang saham oleh penerbit

Merujuk pada pasal 55 POJK 57/2020, penerbit memiliki kewajiban untuk mencatatkan kepemilikan saham pemodal dalam daftar pemegang saham. Apabila karena kelalaian atau keteledoran penerbit yang menyebabkan tidak dicatatnya kepemilikan saham pemodal dalam daftar pemegang saham, maka pemodal dapat mengajukan penyelesaian sengketa ke BAPMI.

b. Litigasi

Langkah hukum secara litigasi melalui lembaga peradilan formal adalah upaya dan langkah hukum terakhir (ultimum remedium) yang dapat diambil dalam penegakan hukum setelah upaya-upaya non-litigasi menemui jalan buntu. Penggunaan upaya hukum atau langkah-langkah hukum secara litigasi dapat dilakukan melalui ranah hukum pidana maupun hukum perdata. Langkah hukum pada ranah hukum pidana akan berakhir pada sanksi hukum berupa hukuman badan (penjara) atau hukuman pengganti (denda atau kurungan). Sedangkan upaya hukum atau langkah hukum pada ranah hukum perdata akan berakhir pada 
sanksi hukum yang salah satunya berupa ganti rugi. ${ }^{38}$ Penyelesaian sengketa secara litigasi terhadap risiko di dalam penyelenggaraan securities crowdfunding dibagi menjadi 2 macam, yaitu yang pertama terhadap risiko ancaman kejahatan dan pertanggungjawaban pidana dan yang kedua terhadap risiko adanya wanprestasi maupun perbuatan melawan hukum untuk dimintakan pertanggungjawaban secara perdata.

1. Risiko berubahnya berubahnya syarat, biaya, manfaat, risiko dan ketentuan yang tercantum pada dokumen/perjanjian serta risiko tidak dicatatnya kepemilikan saham pemodal dalam daftar pemegang saham oleh penerbit, sebagaimana yang sudah dibahas pada non-litigasi

Seperti hal yang sama dibahas dalam penyelesaian sengketa secara non-litigasi, atas risiko yang sama yaitu risiko keterlambatan pengembalian dana, risiko berubahnya berubahnya syarat, biaya, manfaat, risiko dan ketentuan yang tercantum pada dokumen/perjanjian serta risiko tidak dicatatnya kepemilikan saham pemodal dalam daftar pemegang saham oleh penerbit. Ketiga risiko tersebut dapat dikatakan sebuah wanprestasi yang dilakukan oleh suatu pihak, dan juga terdapat potensi di mana salah satu atau lebih pihak melakukan sebuah perbuatan melawan hukum yang dilakukan tanpa didasari dari perjanjian yang disepakati bersama. Perbedaan proses litigasi dan non-litigasi itu dapat dikatakan secara kasuistis. Hal ini dikarenakan seperti yang dikatakan sebelumnya proses litigasi adalah upaya terakhir dalam mencapai suatu keadilan ketika terjadinya suatu sengketa. Proses litigasi akan dilakukan jika terdapat beberapa hal yang harus diperhatikan.

Pertama, bahwa penyelesaian secara non-litigasi melalui external dispute resolution yaitu lembaga arbitrase perlu diperhatikan bahwa hal tersebut sudah dimasukan dan disepakati bersama atau tidak di dalam perjanjian yang telah dibuat. Hal ini berakibat jika, penyelesaian sengketa melalui Lembaga arbitrase tidak dicantumkan dan disepakati bersama di dalam perjanjian, tentu konsekuensi hukumnya lembaga arbitrase tidak berhak menangani penyelesaian sengketa tersebut. Hal tersebut secara konsekuensi hukum proses penyelesaian sengketa secara litigasi diperlukan yang mana lembaga pengadilan yang berwenang adalah Pengadilan

${ }^{38}$ A A Ngurah Deddy Hendra Kesuma, I Nyoman Putu Budiartha, and Puru Ayu Sriasih Wesna, "Perlindungan Hukum Terhadap Keamanan Data Pribadi Konsumen Teknologi Finansial Dalam Transaksi Elektronik,” Jurnal Preferensi Hukum 2, no. 2 (2021): 411-16. 
Negeri untuk memeriksa dan membuktikan gugatan yang diajukan dari salah satu pihak dalam penyelenggaraan securities crowdfunding.

Kedua, secara teori memang putusan lembaga arbitrase itu bersifat final and binding, artinya keputusan tersebut memiliki kekuatan hukum tetap dan mengikat para pihak, jika putusan tersebut dikuatkan oleh Pengadilan Negeri. Hal yang menarik dalam praktik penyelesaian sengketa melalui badan arbitrase, salah satu pihak tidak menerima keputusan tersebut dan mengajukan kembali gugatan dengan membuka kasus dari awal sehingga pihak tersebut tidak mengakui putusan arbitrase. Hal tersebut terkesan menjadi suatu cara berhukum yang salah dan melemahkan marwan lembaga arbitrase. Hal ini perlu dianalisis dan dijelaskan bahwa "putusan arbitrase" itu jelas final and binding. Keputusan lembaga arbitrase itu dilindungi oleh Undang-Undang No. 30 Tahun 1999 tentang Arbitrase dan Penyelesaian Sengketa (UU No.30/1999) sehingga para pihak yang bersengketa melalui lembaga arbitrase tentu harus mematahui putusan tersebut karena kekuatan hukumnya final and binding.

Pada kenyataannya terdapat suatu praktek yang dapat dibenarkan dalam melawan putusan arbitrase, meskipun sifat final and binding. Hal ini bukan bersifat paradoks akan tetapi menjadi cara para pencari keadilan mendapatkan keadilan dalam suatu penyelesaian sengketa. Putusan arbitrase dapat dilawan dengan cara proses litigasi yang mana pada proses arbitrase terdapat unsur-unsur yang menjadikan putusan lembaga arbitrase dirasa kurang adil dan dapat dijadikan diujikan kembali secara litigasi di Pengadilan Negeri. Unsur-unsur yang dimaksud tertuang berdasarkan pasal 70 UU No. 30/1999 yaitu:

a. Surat atau dokumen yang diajukan dalam pemeriksaan, setelah putusan dijatuhkan, diakui palsu atau dinyatakan palsu;

b. Setelah putusan diambil ditemukan dokumen yang bersifat menentukan, yang disembunyikan oleh pihak lawan; atau

c. Putusan diambil dari hasil tipu muslihat yang dilakukan oleh salah satu pihak dalam pemeriksaan sengketa.

Unsur-unsur tersebut memiliki konsekuensi secara alternatif, yang artinya jika terdapat satu unsur tersebut pada putusan arbitrase, maka putusan tersebut dapat diuji dan dibatalkan dengan proses litigasi di Pengadilan jika putusan pengadilan terhadap amar putusannya membatalkan putusan arbitrase, maka permohonan 
pengesahan putusan arbitrase dapat ditolak dan putusan arbitrase tidak memiliki kekuatan hukum secara final and binding.

Berdasarkan kedua hal tersebut dapat dikatakan bahawa penyelesaian sengketa terhadap potensi adanya wanprestasi dan perbuatan melawan hukum dalam penyelenggaraan securities crowdfunding dapat dilakukan melalui proses litigasi dengan memperhatikan dua hal yaitu ada atau tidaknya klausul choice of forum didalam perjanjian securities crowdfunding yang disepakati para pihak dan menganalisis kembali putusan lembaga arbitrase yang telah dibuat terdapat unsur-unsur yang dapat membatalkan putusan lembaga arbitrase meskipun secara teori putusan lembaga arbitrase bersifat final and binding.

2. Risiko terhadap ancaman kejahatan dan bentuk pertanggungjawaban

Berdasarkan penelitian literasi yang dilakukan, terdapat potensi ancaman kejahatan didalam penyelenggaraan securities crowdfunding, yang mana ancaman tersebut perlu dikaji lebih mendalam untuk mengetahui ancaman kejatan dan bentuk pertanggungjawaban yang dapat diajukan secara litigasi terhadap kasus pidana.

1) Risiko Penipuan

Risiko utama dari crowdfunding adalah risiko penipuan yang dilakukan oleh penyelenggara. ${ }^{39}$ Terdapat 3 (tiga) modus penipuan, yaitu: ${ }^{40}$ penipuan yang dilakukan oleh penjual produk atau penyedia jasa kepada konsumen, penipuan dengan menggunakan nama palsu atau martabat palsu dengan akses ilegal terlebih dahulu ataupun di luar dari hubungan produsen konsumen dan penipuan yang dilakukan oleh calon pembeli kepada penjual produk atau penyedia jasa. Untuk risiko penipuan dalam equity crowdfunding masuk dalam modus penipuan yang dilakukan penyedian jasa (penyelenggara) kepada konsumen baik bagi pemodal dataupun penerbit di mana penyelenggara memberikan informasi yang tidak benar atau disembunyikan atas status keuangan perusahaan penyelenggara ataupun penggunaan uang yang telah didapat dari pemodal tidak

39 Betania Jezamin Setiawan and Adrian Azhar Wijanarko, "Crowdfunding: Aspek Kemitraan Pad Penyelenggaraan (Studi Pada Platform Gandengtangan)," Jurnal Manajemen Dan Bisnis Madani 2, no. 2 (2020).

40 Reza Hikmatulloh and Evy Nurmiati, "Analisis Strategi Pencegahan Cybercrime Berdasarkan UU ITE Di Indonesia (Studi Kasus: Penipuan Pelanggan Gojek),” Kosmik Hukum 20, no. 2 (2020): 121-27. 
sesuai dengan tujuan awal. ${ }^{41}$ Terhadap risiko ini, penyelesaian sengketanya adalah dengan melakukan gugatan pidana ke pengadilan atas pasal 90 jo 104 Undang-Undang Nomor 8 Tahun 1995 Tentang Pasar Modal (selanjutnya disebut UUPM). Pasal ini mengatur bahwa para pihak dalam perdagangan efek dilarang baik langsung maupun tidak langsung untuk: a) Melakukan penipuan atau pengelabuan dengan menggunakan sarana atau cara apapun; b) Turut serta menipu; dan c) Membuat suatu pernyatan yang tidak benar terhadap fakta materiel atau tidak mengungkapkan fakta materiel dengan maksud untuk memperoleh keuntungan sendiri atau untuk mempengaruhi pihak lain untuk menjual atau membeli efek.

Pelanggaran terhadap pasal ini diancam dengan pidana penjara paling lama 10 (sepuluh) tahun dan denda paling banyak Rp15.000.000.000,00 (lima belas milyar rupiah). Kemudian penipuan pada securities crowdfunding juga dapat dikenakan pasal 28 ayat (1) UU ITE jo. Pasal 45A ayat (1) Perubahan UU ITE, di mana unsur-unsurnya:

a. Korban adalah konsumen,

b. Terdapat berita bohong yang mengakibatkan kerugian konsumen, dan

c. Berita bohong tersebut disebarkan atau disampaikan menggunakan transmisi, distribusi, dan/atau dapat diaksesnya suatu informasi elektronik dan/atau dokumen elektronik.

Penipuan ini menghukum pelakunya dengan pidana penjara paling lama 6 (enam) tahun dan/atau denda paling banyak Rp1.000.000.000,00 (satu milyar rupiah).

2) Risiko peretasan pada platform penyelenggara dan data pribadi pemodal

Data pribadi sangat sensitif sehingga diperlukan adanya perlindungan khusus atas data pribadi. Data pribadi terdiri dari data yang berkaitan dengan agama/keyakinan, kesehatan, kondisi fisik dan kondisi mental, kehidupan seksual, data keuangan pribadi, dan data pribadi lainnya yang mungkin dapat membahayakan dan merugikan privasi subjek data apabila data

${ }^{41}$ Setiawan and Wijanarko, "Crowdfunding: Aspek Kemitraan Pad Penyelenggaraan (Studi Pada Platform Gandengtangan).” 
tersebut diretas atau bocor. ${ }^{42}$ Penyelenggara berkewajiban menjalankan sistem elektronik secara aman dan andal serta bertanggung jawab atas beroperasinya sistem elektronik sesuai pada peraturan perundang-undangan di bidang komunikasi dan informatika. Pada risiko ini dilakukan penyelesaian sengketa dengan melakukan gugatan perbuatan melawan hukum secara perdata melalui Pengadilan Negeri. Apabila karena adanya pelanggaran atas perjanjian yang disepakati di mana dalam perjanjian tersebut ada hubungan kontraktual antar para pihak kemudian dari hubungan kontraktual tersebut menimbulkan kerugian pada pemodal maka dapat diajukan gugatan wanprestasi. Sedangkan apabila tidak adanya hubungan kontraktual antara pihak, maka dapat diajukan gugatan berupa perbuatan melawan hukum ke Pengadilan Negeri setempat untuk tingkat pertama. Gugatan perdata bertujuan untuk memulihkan (recovery) kerugian penggugat dengan sanksi denda atau ganti rugi yang dijatuhkan kepada tergugat jika terbukti bersalah.

3) Risiko penggunaan dana pada escrow account dari pembelian efek oleh pemodal selain untuk penampungan dana.

Merujuk pada pasal 38 ayat (7) POJK 58/2020, escrow account digunakan sebagai penampungan dana pembelian efek oleh pemodal dan dilarang digunakan untuk selain dari fungsi tersebut. Apabila penyelenggara memiliki itikad tidak baik di mana misalnya penyelenggara menggunakan dana dari pemodal untuk kepentingan pribadi, maka pemodal dapat menyelesaikan sengketa dengan melakukan tuntutan pidana ke Pengadilan Negeri atas pasal 372 KUHP yaitu terkait penggelapan. Penggelapan memiliki unsur objektif dan subjektif. Unsur objektif dari penggelapan antara lain perbuatan memiliki, sesuatu benda (eenig goed), yang sebagian atau seluruhnya milik orang lain, yang berada dalam kekuasaannya bukan karena kejahatan. Sedangkan unsur subjektif dari penggeapan

\footnotetext{
42 Ardhiana Hidayah and Marsitiningsih Marsitiningsih, "Aspek Hukum Perlindungan Data Konsumen E-Commerce,” Kosmik Hukum 20, no. 1 (2020): 56-63.
} 


\section{PENUTUP}

meluputi penggelapan dengan sengaja (opzettelijk) dan penggelapan melawan hukum (wederechtelijk). ${ }^{43}$

Meskipun POJK 57/2020 mengenai pengaturan securities crowdfunding di Indonesia tidak termuat dalam dalam jenis dan hierarki peraturan perundang-undangan di Indonesia akan tetapi berdasarkan pasal 7 ayat (1) UU 12/2012, bahwa POJK 57/2020 termasuk ke dalam peraturan yang tidak termasuk dalam jenis dan hierarki peraturan perundang-undangan akan tetapi tetap diakui keberadaannya serta memiliki kekuatan hukum mengikat selama masih diperintahkan oleh peraturan perundang-undangan yang lebih tinggi di mana hal ini berdasarkan pasal 8 ayat (1) dan (2) UU 12/2011. Oleh karena itu, dapat dikatakan bahwa POJK 57/2020 ini memiliki kekuatan hukum mengikat dan konsekuensi hukumnya adalah segala bentuk praktek security crowdfunding di Indonesia tunduk dan patuh pada ketentuan POJK 57/2020 yang diatur dan diawasi oleh Otoritas Jasa Keungan. Kemudian terhadap penyelesaian sengketa atas risiko dalam penyelenggaraan securities crowdfunding dapat dilakukan dengan 2 cara, yaitu secara non-litigasi dan litigasi. Penyelesaian sengketa secara non-litigasi terbagi menjadi 2 forum yaitu forum internal dispute resolution yang diselenggarakan oleh platform penyelenggara dan forum external dispute resolution yang diselenggarakan oleh lembaga arbitrase yang berwenang. Mengenai penyelesaian sengketa secara litigasi terbagi menjadi 2 kategori risiko perkara yaitu risiko terhadap potensi adanya wanprestasi dan perbuatan melawan hukum dengan memperhatikan ada atau tidaknya klausul choice of forum.

\section{DAFTAR PUSTAKA}

Antariksa, Bambang. "Penerapan Hierarki Peraturan Perundang-Undangan Dalam Ketatanegaran Indonesia.” Deliberatif 1, no. 1 (2017): 24-41.

Aprihasyyati, Dalilatiyani Ajrinatia, and Shoimatul Fitria. "Analisis Pengaruh Kinerja UMKM, Kepercayaan Dan Persepsi Risiko Terhadap Niat Investasi Pada UMKM Melalui Platform Equity Crowdfunding Di Indonesia." Diponegoro Journal of Management 9, no. 2 (2021).

Arifin, Arifin. "Eksistensi Peraturan Daerah Dalam Sistem Hukum Nasional Dan Implementasinya Terhadap Otonomi Daerah.” Tadulako University, 2015.

Asshiddiqie, Jimly, and Muchamad Ali Safa'at. Teori Hans Kelsen Tentang Hukum. Mahkamah Konstitusi RI, Sekretariat Jenderal dan

\footnotetext{
${ }^{43}$ Mazmur Septian Rumapea, "Perlindungan Hukum Terhadap Penggelapan Uang Elektronik Dalam Transaksi Elektronik," Jurnal Hukum Kaidah: Media Komunikasi Dan Informasi Hukum Dan Masyarakat 18, no. 3 (2019): 27-39.
} 
Kenpaniteraan, 2006.

Belleflamme, Paul, Thomas Lambert, and Armin Schwienbacher. "Crowdfunding: Tapping the Right Crowd." Journal of Business Venturing 29, no. 5 (2014): 585-609.

Cumming, Douglas, Michele Meoli, and Silvio Vismara. "Does Equity Crowdfunding Democratize Entrepreneurial Finance?" Small Business Economics 56, no. 2 (2021): 533-52. https://doi.org/10.1007/s11187-019-00188-z.

Hariyani, Iswi. "Perlindungan Hukum Dan Penyelesaian Sengketa Bisnis Jasa PM-Tekfin.” Jurnal Legislasi Indonesia 14, no. 3 (2018): 345-58.

Hartanto, Ratna. "Hubungan Hukum Para Pihak Dalam Layanan Urun Dana Melalui Penawaran Saham Berbasis Teknologi Informasi." Jurnal Hukum Ius Quia Iustum 27, no. 1 (2020): 151-68.

Hasan, Hasbi. "Efektivitas Pengawasan Otoritas Jasa Keuangan Terhadap Lembaga Perbankan Syariah." Jurnal Legislasi Indonesia 9, no. 3 (2012): 373-94.

Hidayah, Ardhiana, and Marsitiningsih Marsitiningsih. "Aspek Hukum Perlindungan Data Konsumen E-Commerce." Kosmik Hukum 20, no. 1 (2020): 56-63.

Hikmatulloh, Reza, and Evy Nurmiati. "Analisis Strategi Pencegahan Cybercrime Berdasarkan UU ITE Di Indonesia (Studi Kasus: Penipuan Pelanggan Gojek)." Kosmik Hukum 20, no. 2 (2020): 121-27.

Huda, Ni'matul. "Kedudukan Peraturan Daerah Dalam Hierarki Peraturan Perundang-Undangan.” Jurnal Hukum Ius Quia IusTum 13, no. 1 (2006): 27-37.

Indonesia, PT Joinan Kapital. "No Title." Disclaimer, n.d. https://www.joinan.co.id/legal\#syarat-ketentuan-pemodal.

Indrati, Maria Farida. "Ilmu Perundang-Undangan: Dasar-Dasar Dan Pembentukannya." Jakarta. Kanisius, 1998.

Juniar, Deza Pasma, Agus Suwandono, and Helitha Novianty Muchtar. "Perlindungan Hukum Terhadap Konsumen Peer To Peer Lending Atas Perbuatan Melawan Hukum Yang Dilakukan Oleh Debt Collector." Widya Yuridika: Jurnal Hukum 3, no. 2 (2020): 107-18.

Kadir, Muhammad Rusydi. "Shariah Compliance Pada Investasi Sukuk Dalam Securities Crowdfunding Di Indonesia." Jurnal Ilmu Perbankan Dan Keuangan Syariah 3, no. 1 (2021): 16-29.

Kasmir, S E. "Bank Dan Lembaga Keuangan Lainnya Edisi Revisi," 2018.

Kesuma, A A Ngurah Deddy Hendra, I Nyoman Putu Budiartha, and Puru Ayu Sriasih Wesna. "Perlindungan Hukum Terhadap Keamanan Data Pribadi Konsumen Teknologi Finansial Dalam Transaksi Elektronik." Jurnal Preferensi Hukum 2, no. 2 (2021): 411-16.

Marzuki, Peter Mahmud. "Penelitian Hukum, Edisi Pertama, Cet." VII, Kencana Prenada (Jakarta, Media Group, 2011), 2011.

—. "Penelitian Hukum (Edisi Kesatu)." Jakarta, Kencana, 2010.

Muadzan, Teuku Ghalib, and Bernardus Yuliarto Nugroho. "Analisis Optimasi Model Bisnis Perusahaan Fintech Berbasis Equity Crowdfunding 
Menggunakan Business Model Canvas." Syntax Literate; Jurnal Ilmiah Indonesia 6, no. 6 (2021).

Philipus, M Hadjon. "Perlindungan Hukum Bagi Rakyat Indonesia." Bina Ilmu, Surabaya 25 (1987).

Prahastoro, Gigih, Firdaus Yuni Dharta, and Rastri Kusumaningrum. "Strategi Komunikasi Pemasaran Layanan Securities Crowdfunding Dalam Menarik Minat Masyarakat Untuk Berinvestasi Di Sektor UKM.” Kinerja 18, no. 2 (2021): 210-17.

Purnami, Tika. "Perlindungan Hukum Bagi Debitur Dalam Pinjaman Online Berbasis Peer To Peer Lending." Jurnal Kertha Wicara 9, no. 12 (2020): $1-10$.

Rahyani, Wiwin Sri. "Independensi Otoritas Jasa Keuangan Dalam Perspektif Undang-Undang Nomor 21 Tahun 2011 Tentang Otoritas Jasa Keuangan (The Independence Of The Financial Services Authority Perspectives In Law Number 21 Year 2011 Concerning The.” Daftar Isi, n.d., 361.

Rumapea, Mazmur Septian. "Perlindungan Hukum Terhadap Penggelapan Uang Elektronik Dalam Transaksi Elektronik." Jurnal Hukum Kaidah: Media Komunikasi Dan Informasi Hukum Dan Masyarakat 18, no. 3 (2019): 27-39.

Saputra, Mochamad Dandy Hadi, and Vika Annisa Qurrata. "Securities Crowdfunding: Bagaimana Relevansinya Pada Nilai-Nilai Pancasila?" In Prosiding Seminar Nasional Ekonomi Pembangunan, 1:28-37, 2021. Setiawan, Betania Jezamin, and Adrian Azhar Wijanarko. "Crowdfunding: Aspek Kemitraan Pada Penyelenggaraan (Studi Pada Platform Gandengtangan)." Jurnal Manajemen Dan Bisnis Madani 2, no. 2 (2020).

Setyonagoro, Permadi. "Wacana Hukum Uji Konstitusionalitas Produk Hukum Peraturan Daerah (Legal Discourse About Testing Constitutionality Of Regional Regulations)." Cakrawala 13, no. 1 (2019).

Shafi, Kourosh. "Investors' Evaluation Criteria in Equity Crowdfunding." Small Business Economics 56, no. 1 (2021): 3-37. https://doi.org/10.1007/s11187-019-00227-9.

Soeprapto, Maria Farida Indrati. Ilmu Perundang-Undangan 2: Proses Dan Teknik Penyusunan. PT Kanisius, 2018.

Sugiarti, Evy Nur, Nur Diana, and M Cholid Mawardi. "Peran Fintech Dalam Meningkatkan Literasi Keuangan Pada Usaha Mikro Kecil Menengah Di Malang." Jurnal Ilmiah Riset Akuntansi 8, no. 04 (2019).

Susanti, Bivitri. "Menyoal Jenis Dan Hierarki Peraturan Perundang-Undangan Di Indonesia." Jentera: Jurnal Hukum 1, no. 2 (2017): 128-43.

Syahuri, Taufiqurrohman. Hukum Konstitusi: Proses Dan Prosedur Perubahan UUD Di Indonesia 1945-2002 Serta Perbandingannya Dengan Konstitusi Negara Lain Di Dunia. Ghalia Indonesia, 2004.

Winarta, Frans Hendra. "Hukum Penyelesaian Sengketa," 2013. 